\title{
Reference
}

Escher, J. C: \& Myers, J. S. 1974: New evidence concerning the original relationships of early Precambrian volcanics and anorthosites in the Fiskenæsset region, southern West Greenland. Rapp. Grønlands geol. Unders. 75, 72-77.

R. T. P., Scottish Research Reactor Centre,

East Kilbride, Glasgow, Scotland.

\section{Stratigraphy of the Fiskenæsset anorthosite complex, southern West Greenland, and comparison with the Bushveld and Stillwater complexes}

\author{
John S. Myers
}

The Fiskenæsset complex is a thin layered sheet of deformed and metamorphosed anorthosite, leucogabbro, gabbro, peridotite and dunite, with numerous chromitite layers and lenses. It occurs in an Archaean terrain of amphibolite and granulite facies gneisses as layers up to $500 \mathrm{~m}$ thick with outcrop lengths of up to $25 \mathrm{~km}$ and as trains of fragments in gneisses, in a belt $50 \mathrm{~km}$ wide and $100 \mathrm{~km}$ long in the Fiskenæsset region (fig. 28). The Fiskenæsset complex has given an $\mathrm{Rb} / \mathrm{Sr}$ whole rock age of $2810 \pm 120 \mathrm{~m}$.y. (Alexander et al., 1973), and gneisses which cut it have given an $\mathrm{Rb} / \mathrm{Sr}$ whole rock age of $2880 \pm 50 \mathrm{~m}$. y. (Moorbath \& Pankhurst, in press) and a U/Pb zircon age of $2835 \pm 10 \mathrm{~m}$. y. (Pidgeon et al., 1976). $\mathrm{A} \mathrm{Pb} / \mathrm{Pb}$ whole rock age of $2810 \pm 70 \mathrm{~m}$.y. from both anorthosite and gneiss from Fiskenæsset has been interpreted as the age of metamorphism (Black et al., 1973).

The Fiskenæsset complex was intruded as a sill into basic volcanic rocks which are now amphibolites (Escher \& Myers, 1975). It was then disrupted by thrusting and the intrusion of sheets of granitoid rocks which are now gneisses (Myers, 1976a \& b) and these rocks were repeatedly deformed and metamorphosed. These events confused and blurred the original igneous stratigraphy of the Fiskenæsset complex, and the complete stratigraphy is no longer intact at any one locality.

Early descriptions of parts of the stratigraphy of the Fiskenæsset complex were given by Gormsen (1971), Windley (1971), Windley et al. (1973) and Hutt (1974), and more recently by Myers (1975). During 1975 the author visited all the main outcrops of the Fiskenæsset complex in order to correlate the stratigraphy throughout the whole Fiskenæsset region. A large number of new sections were measured and mapped in detail, and previously described sections were reappraised in the light of newly discovered way-up structures and the overall stratigraphy and structure of the region.

The complete stratigraphy of the Fiskenæsset complex deduced from this field study is shown in Table 9, where it is compared with the stratigraphy described from Qeqertarssuat- 


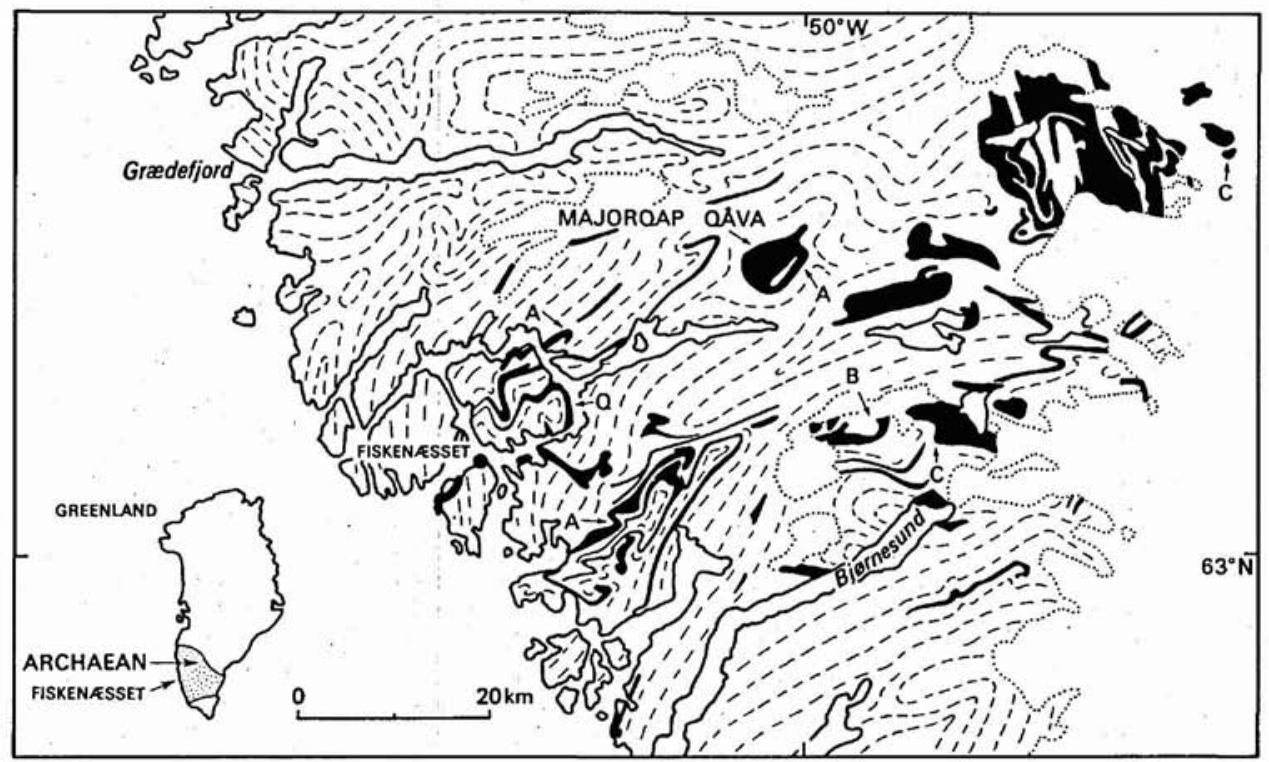

Fig. 28. Sketch map of the Fiskenæsset region, southern West Greenland, showing the distribution of the Fiskenæsset anorthosite complex (black), simplified compositional layering of gneisses and amphibolites (thin broken lines) and ice boundaries (dots); after Myers (1975). Q locates Qeqertarssuatsiaq; A,

$\mathrm{B}$ and $\mathrm{C}$ locate suggested type localities of parts of the anorthosite complex.

siaq by Windley (1971, 1973), and from Majorqap qâva by Myers (1975). The main addition to the previously described stratigraphy is a unit of gabbro on top of the anorthosite unit at the top of the whole succession, and the widespread occurrence of a unit of gabbro at the base of the sequence below the ultramafic unit. Thin distinctive horizons were also observed in widely scattered outcrops of the complex which suggest that most of the anorthositic

Table 9. Correlation of the stratigraphy of the Fiskenasset anorthosite complex

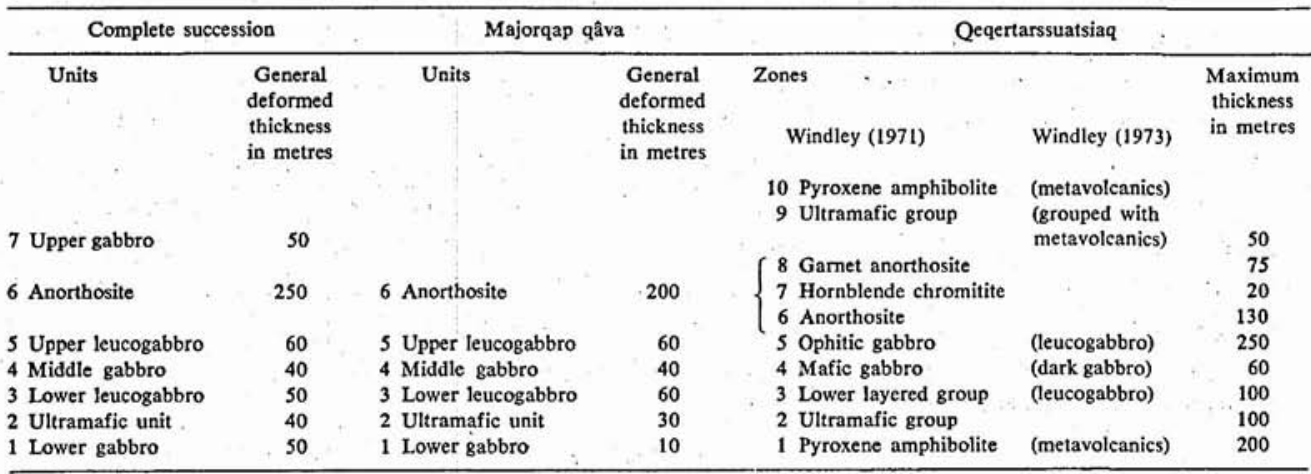

(after Myers, 1975) 
layers and fragments of the whole region are part of the same intrusive complex rather than part of a number of intrusive complexes.

\section{Stratigraphy of the Fiskenasset complex}

The lower gabbro unit consists of layers of gabbro, melanogabbro and leucogabbro in which gabbro is dominant. The rocks are generally strongly deformed, thoroughly recrystallised and consist of plagioclase and hornblende. Igneous textures are only preserved in a few places.

The ultramafic unit consists of a number of cyclic mineral-graded sub-units of dunite, peridotite and hornblende rock, which are interpreted as olivine, olivine + pyroxene \pm hornblende, and pyroxene \pm hornblende cumulates respectively.

The lower leucogabbro unit mainly consists of both isomodal and mineral-graded layers of leucogabbro (plagioclase cumulate) with minor mineral-graded layers of dunite, peridotite, melanogabbro and gabbro. Igneous textures and minerals are well preserved in many places.

The middle gabbro unit is composed of isomodal gabbro, plagioclase + hornblende rock, with minor mineral-graded peridotite and gabbro-leucogabbro layers.

The upper leucogabbro unit mainly consists of coarse-grained isomodal leucogabbro (plagioclase cumulate). A number of mineral-graded peridotite layers are interlayered with plagioclase and plagioclase + chromite cumulates at the base of the unit, and in some places a major horizon of plagioclase + chromite cumulate occurs at the top of the unit. Igneous textures and minerals are well preserved in many places.

The anorthosite unit is generally more strongly deformed than the lower units and consists of anorthosite with small schlieren of leucogabbro with metamorphic textures. The anorthosite contains thin discontinuous layers of coarse-grained and less deformed plagioclase and plagioclase + chromite cumulates. The uppermost part of the unit contains more hornblende than the lower part, and it approaches leucogabbro in composition and contains numerous metamorphic garnets.

The upper gabbro unit consists of thin layers of gabbro and leucogabbro, plagioclase + hornblende rocks, with minor layers of dunite and peridotite. Magnetite occurs as a major cumulus mineral in both the plagioclase and ultramafic cumulates, and in some places it forms almost massive layers up to $50 \mathrm{~cm}$ thick.

Suggested type localities where the stratigraphy of the various units of the complex is best preserved are marked on fig. 28 . Three places where the lower gabbro and ultramafite units are equally but not ideally preserved are marked $\mathrm{A}$. The lower leucogabbro, middle gabbro, upper leucogabbro and lower part of the anorthosite units are best preserved at Majorqap qâva, the upper part of the anorthosite unit is best exposed at locality B and the upper gabbro unit at localities marked C.

\section{Discussion}

The overall stratigraphy of the Fiskenæsset complex has close similarities with the major sequence of rock units of the better known Bushveld and Stillwater complexes (fig. 29). 
BUSHVELD

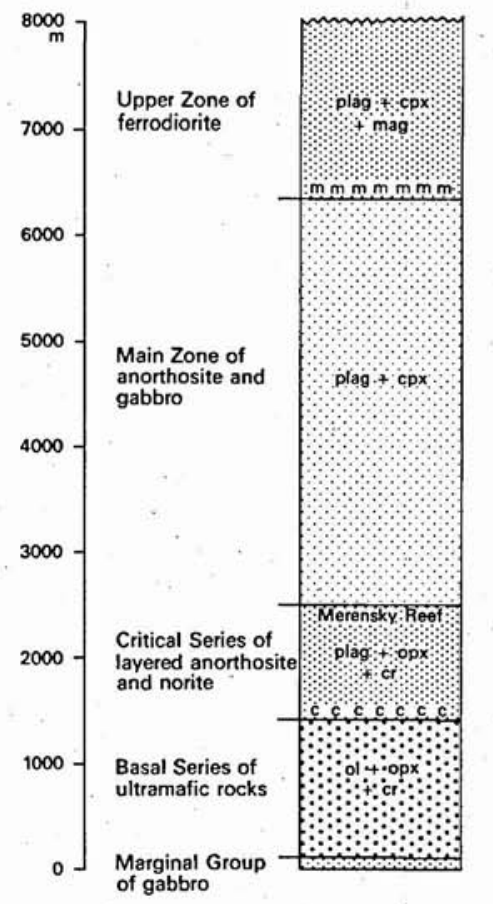

FISKENESSET



STILLWATER
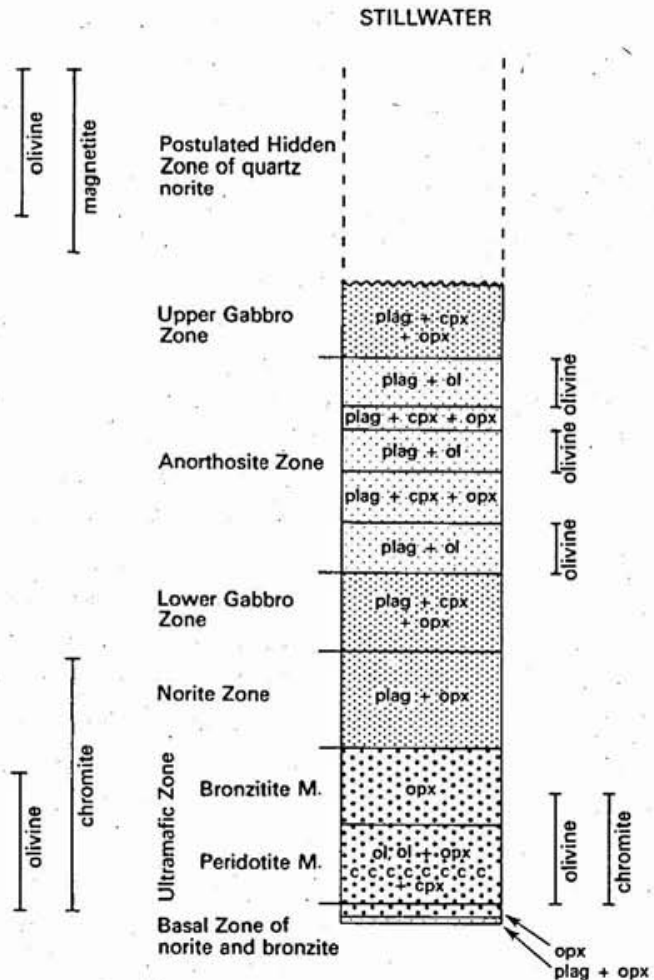

Fig. 29. Comparison of the simplified stratigraphies of the Bushveld, Stillwater and Fiskenæsset complexes. Bushveld complex after Wager \& Brown (1968, p. 351); Stillwater complex, Basal and Ultramafic Zones after Page \& Nokleberg (1974), other zones after Hess (1960, p. 50). Note the different scale of the Fiskenæsset complex compared with that of the Bushveld and Stillwater complexes. Abbreviations: plag-plagioclase, ol-olivine, opx-orthopyroxene, $\mathrm{cpx}$-clinopyroxene, cr-chromite, mag - magnetite. 
All these three layered intrusions are composed of a unit of gabbro at the bottom which is overlain successively by major units of ultramafic rocks, gabbro, and anorthosite, with a major unit of gabbro, norite or diorite at the top. All three intrusions, like the Skaergaard intrusion, show upward enrichment in iron (Wager \& Brown, 1968). In the Bushveld and Fiskenæsset complexes cumulus chromite was precipitated early and cumulus magnetite late in the sequence, as in the Cuillin layered intrusion of Skye (Wager \& Brown, 1968, p. 423). Cumulus olivine was precipitated early (fig. 29), and then after its absence in the middle part of the Bushveld and Fiskenæsset sequences, it appears as a cumulus phase in the uppermost part of the intrusions. A similar situation exists in the Skaergaard intrusion and is explained in terms of fractionation of the system $\mathrm{Mg} 0-\mathrm{Fe} 0-\mathrm{SiO}_{2}$ (Wager \& $\mathrm{Brown}, 1968$ ).

The distribution of chromite in the Fiskenæsset complex appears to be slightly different from that in the Bushveld and Stillwater complexes where chromite mainly occurs in the ultramafic zones with cumulus olivine and bronzite. In the Fiskenæsset complex most chromite was precipitated after the accumulation of olivine in the lower part of the intrusion. Although this situation is very different from the Stillwater complex and the Basal Series of the Bushveld complex, it is similar to that in the Critical Series of the Bushveld complex where chromite was intermittently precipitated with bronzite and plagioclase and formed thin contrasting layers of plagioclase-rich and chromite-rich cumulates, similar to layers in the upper leucogabbro and anorthosite units of the Fiskenæsset complex. When the thickness of the Fiskenæsset complex is considered, the similarity between the Fiskenæsset complex and the Critical Series of the Bushveld complex is even more marked.

The Fiskenæsset complex differs from the Bushveld and Stillwater complexes in that it is strongly deformed and metamorphosed, and mainly consists of hornblende rather than pyroxene- or olivine-bearing rocks. But it is not known whether most of the hornblende was derived from igneous hornblende or pyroxene. In spite of modifications by deformation, the original thickness of the Fiskenæsset complex does not appear to have approached the thickness of the Bushveld and Stillwater complexes.

\section{Conclusions}

The general stratigraphy of the Fiskenæsset complex is therefore not as unusual, compared with the Bushveld and Stillwater complexes, as was thought previously (Windley et al., 1973). Although each layered intrusion shows a unique sequence of events, the general sequence of crystallisation and the processes which governed it appear to be similar in these three major layered intrusions.

\section{References}

Alexander, E. C., Evensen, N. M. \& Murthy, V. R. 1973: ${ }^{40} \mathrm{Ar}-{ }^{39} \mathrm{Ar}$ and Rb-Sr studies of the Fiskenæsset complex, West Greenland. Trans. Amer. geophys. Un. 54, p. 1227 only.

Black, L. P., Moorbath, S., Pankhurst, R. J. \& Windley, B. F. 1973: ${ }^{207} \mathrm{~Pb} /{ }^{206} \mathrm{~Pb}$ whole rock age of the Archaean granulite facies metamorphic event in West Greenland. Nature, Phy. Sci. 244, 50-53.

Escher, J. C. \& Myers, J. S. 1975: New evidence concerning the original relationships of early Precambrian volcanics and anorthosites in the Fiskenæsset region, southern West Greenland. Rapp. Grønlands geol. Unders. 75, 72-76. 
Gormsen, K. 1971: En geologisk undersøgelse af det chromitførende Fiskenæsset kompleks omkring Taseq, Vestgrønland. Unpubl. thesis, Univ. Copenhagen, 99 pp.

Hess, H. H. 1960: Stillwater igneous complex, Montana; a quantitative mineralogical study.Mem. geol. Soc. Am. 80, 230 pp.

Hutt, D. K. 1974: The geology and geochemistry of part of the Fiskenæsset anorthosite complex, West Greenland. Unpubl. Ph. D. thesis, Univ. London, $316 \mathrm{pp}$.

Moorbath, S. \& Pankhurst, R. J. in press: Further rubidium-strontium age and isotope evidence for the nature of the Late Archaean plutonic event in West Greenland. Nature. Lond.

Myers, J. S. 1975: Igneous stratigraphy of Archaean anorthosite at Majorqâp qâva, near Fiskenæsset, South-West Greenland. Rapp. Gronlands geol. Unders. 74, 27 pp.

Myers, J. S. 1976a: Acid and intermediate intrusions, deformation and gneiss formation north-east of Fiskenæsset. Rapp. Grønlands geol. Unders. 73, 7-15.

Myers, J. S. 1976b: Granitoid sheets, thrusting and Archaean crustal thickening in West Greenland. Geology, 4, 265-268.

Page, N. J. \& Nokleberg, W. J. 1974: Geologic map of the Stillwater complex, Montana. U. S. Geol. Surv. Map I-797.

Pidgeon, R. T., Aftalion, M. \& Kalsbeek, F. 1976: The age of the Ilivertalik granite in the Fiskenæsset area. Rapp. Grønlands geol. Unders. 73, 31-33.

Wager, L. R. \& Brown, G. M. 1968: Layered igneous rocks, 588 pp. Edinburgh \& London: Oliver \& Boyd.

Windley, B. F. 1971: The stratigraphy of the Fiskenæsset anorthosite complex. Rapp. Grønlands geol. Unders. 35, 19-21.

Windley, B. F. 1973: The chemistry of the Fiskenæsset complex on Qeqertarssuatsiaq. Rapp. Grønlands geol. Unders. 51, 41-46.

Windley, B. F., Herd, R. K. \& Bowden, A. A. 1973: The Fiskenæsset complex, West Greenland. Part I: A preliminary study of the stratigraphy, petrology, and whole rock chemistry from Qeqertarssuatsiaq. Bull. Grønlands geol. Unders. 106 (also Meddr Grønland 196, 4), 80 pp.

\title{
Detailed mapping in the southern part of the Ilimaussaq alkaline intrusion, South Greenland
}

\author{
Steen Andersen, Jens Christensen, \\ Karsten Mæhl and Peter Normann
}

Detailed mapping was continued during the 1975 field season in the southern part of the Ilimaussaq intrusion (Andersen et al., 1973; Andersen, 1974). Work was aimed at elucidation of the age relationships between the main rock types: sodalite-foyaite, naujaite, black arfvedsonite-lujavrite and green aegirine-lujavrite.

One of us (S. A.) enlarged the detailed map of the lujavrite breccia by another $1.5 \mathrm{~km}^{2}$ in the region of Agpat. The geological pattern in this area corresponds to that previously found around hill $435 \mathrm{~m}$ although it is now clear that two generations of green lujavrite can be distinguished in addition to the black lujavrite. The older generation of green lujavrite pre-dates the black lujavrite. In contrast, the younger generation is contemporaneous with the black lujavrite and formed from the same magma pulse. This development endorses the 